\title{
KONFLIK BATIN TOKOH UTAMA DALAM NOVEL ASSALAMUALAIKUM BEIJING KARYA ASMA NADIA
}

\author{
Nofa Putri ${ }^{1}$, Silva Kastari ${ }^{2}$, Syahrul Ramadhan ${ }^{3}$ \\ Fakultas Bahasa dan Seni, Universitas Negeri Padang

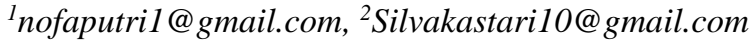

\begin{abstract}
Abstrak
Artikel ini bertujuan untuk menemukan dan mendeskripsikan konflik batin yang dialami oleh tokoh utama dalam novel Assalamualaikum Beijing karya Asma Nadia. Berdasarkan tujuan tersebut, maka metode yang akan digunakan dalam penelitian ini menggunakan metode deskriptif kualitatif. Hasil penelitian menunjukkan bahwa terdapat tiga konflik batin yang dialami tokoh utama dalam novel Assalamualaikum Beijing karya Asma Nadia. Konflik batin tersebut adalah id, ego, dan super ego. Konflik batin id yang dialami tokoh utama terjadi pada saat Asma membatalkan pernikahannya dengan Dewa karena Dewa telah mengkhianatinya. Konflik batin ego yang dialami tokoh utama terjadi pada saat Asma sakit dan tidak mau lagi melanjutkan hubungannya dengan Zhongwen. Konflik batin super ego yang dialami tokoh utama terjadi pada saat Asma pergi ke Beijing untuk melupakan sakit hatinya kepada Dewa.
\end{abstract}

Kata Kunci: konflik batin, metode deskriptif, tokoh utama.

\begin{abstract}
This article aims to find and describe the inner conflict experienced by the main character in the Assalamualaikum Beijing novel by Asma Nadia. Based on these objectives, the method to be used in this study uses a qualitative descriptive method. The results showed that there were three inner conflicts experienced by the main character in the Assalamualaikum Beijing novel by Asma Nadia. These inner conflicts are id, ego, and super ego. The inner conflict of the id experienced by the main character occurred when Asma canceled her marriage to a god because the god had betrayed her. The inner conflict of the ego experienced by the main character happened when Asma was sick and refused to continue her relationship with Zhongwen. The super ego inner conflict experienced by the main character happened when Asma went to Beijing to forget her heartache to God.
\end{abstract}

Keywords: inner conflict, descriptive method, main character.

\section{PENDAHULUAN}

Konflik adalah suatu pertentangan atau perselisihan yang terjadi pada seseorang mengenai suatu hal. Konflik dapat terjadi pada siapa pun dan di mana pun seseorang berada. Konflik batin merupakan konflik pribadi yang disebabkan karena adanya dua atau lebih keinginan atau gagasan yang saling bertentangan dan menguasai diri individu sehingga memengaruhi sikap, perilaku, tindakan, dan keputusannya. Konflik batin tidak 
muncul dengan sendirinya, melainkan melalui proses yang panjang dan berlarut-larut. Penyebab terjadinya konflik batin dapat bersumber dari diri sendiri, keluarga, teman, ataupun lingkungan masyarakat.

Konflik batin merupakan hal yang paling erat kaitannya dengan emosional individu sehingga hal ini menyebabkan tingkat keresahan paling tinggi. Konflik dapat muncul karena dua hal, yaitu kelebihan beban dan ketidaksesuaian seseorang dalam melaksanakan peranan. Menurut Ahmadi (2007:286), pada kondisi seseorang mengalami kelebihan beban hal ini disebabkan karena status atau kedudukan yang dimilikinya. Pada kondisi yang kedua seseorang memang tidak memiliki kesesuaian untuk melaksanakan peran sesuai dengan statusnya.

Charles (dalam Arifuddin, 2014) mengatakan bahwa konflik adalah oposisi yang dihadirkan pada tokoh utama dari narasi oleh karakter lain, peristiwa, situasi, nasib, aspek dari kepribadian, atau sifat protagonis sendiri. Konflik diperkenalkan dengan cara komplikasi yang menggerakkan tindakan dan meningkatkan klimaks dan resolusi akhir. Stanton (dalam Arifuddin, 2014) mengatakan bahwa konflik adalah aresistensi fisikal, moral, pikiran, emosi, takdir di antara manusia, hewan, atau bahkan dalam diri kita. Konflik diilustrasikan sebagai pertentangan antara protagonis dan antagonis.

Ristiana dan Ikin (2017) mengatakan bahwa konflik batin ini merupakan masalah intern bagi seorang manusia. Misalnya, ada sesuatu hal yang terjadi akibat adanya pertentangan antara dua keinginan, keyakinan, pilihan yang berbeda, harapan-harapan, atau masalah-masalah lainnya. Dalam novel, konflik batin ini banyak mengeksplorasi berbagai masalah kejiwaan dengan menggunakan sudut pandang orang pertama (gaya aku). Konflik batin dimunculkan dalam karya fiksi untuk menentukan kualitas, intensitas dan kemenarikan suatu karya. Bahkan bisa dikatakan bahwa menulis cerita sebenarnya tidak lain adalah untuk membangun dan mengembangkan konflik. Konflik itu bisa dicari, ditemukan, diimajinasikan, dan dikembangan berdasarkan konflik yang dapat ditemui di dunia nyata.

Banyaknya permasalahan atau konflik pada kehidupan nyata yang disuguhkan seorang penulis melalui karyanya, menjadikan sebuah karya sastra mengandung aspekaspek kejiwaan yang sangat kaya. Peristiwa-peristiwa manusiawi yang saling berkaitan antara satu dengan yang lainnya menyebabkan munculnya beberapa konflik, biasanya akan banyak diminati oleh pembaca. Bahkan, sebenarnya yang dihadapi dan menyita perhatian pembaca ialah konflik yang semakin memuncak ke klimaks dan penyelesaiannya. Konflik inilah yang akan secara langsung membangkitkan ketegangan dan rasa ingin tahu akan kelanjutan dan penyelesaian cerita.

Kemenarikan fiksi di antaranya dapat ditentukan dari adanya konflik yang dialami tokoh utama dalam novel Assalamualaikum Beijing. Bagaimana belajar tentang sebuah keikhlasan dalam menghadapi segala ujian sehingga terlahirnya suatu konflik inilah yang ingin dihadirkan oleh Asma Nadia dalam novel Assalamualaikum Beijing.

Pentingnya menghadirkan konflik dalam suatu cerita tidak dapat disangkal. Dalam karya sastra, konflik menjadi dasar narasi yang kuat dan menjadi bagian penting dalam pengembangan alur atau plot pada sebuah cerita yang bersumber dari kehidupan. Oleh karena itu, konflik mempunyai peranan penting untuk menarik perhatian pembaca dan tidak jarang pembaca akan terlibat secara emosional atas apa yang terjadi dalam cerita. Stanson (1965:16) (dalam Nurgiyantoro, 2013:181) mengatakan bahwa bentuk konflik sebagai bentuk peristiwa dapat pula dibedakan ke dalam dua kategori: konflik fisik dan konflik batin, konflik eksternal (external conflict) dan konflik internal (internal conflict). Segala fiksi pasti mengandung konflik dan sebuah konflik terjadi bisa berdasar 
pada sebuah kehidupan. Dalam sebuah cerita tentu saja kehidupan yang dimaksud adalah kehidupan antartokoh.

Jones (dalam Nurgiyantoro (2013:181) mengatakan juga bahwa konflik eksternal adalah konflik yang terjadi antara seorang tokoh dengan sesuatu yang di luar dirinya, mungkin dengan lingkungan alam, mungkin dengan lingkungan manusia atau tokoh lainnya. Dengan demikian, konflik eksternal dapat dibedakan ke dalam dua kategori, yaitu konflik fisik (pshycal conflict) dan konflik sosial (social conflict). Selain itu, Nurgiyantoro (2013:181) menjelaskan juga bahwa "Konflik internal (atau: konflik kejiwaan, konflik batin) adalah konflik yang terjadi dalam hati dan pikiran, dalam jiwa seorang tokoh (atau tokoh-tokoh) cerita. Jadi, ia merupakan konflik yang dialami manusia dengan dirinya sendiri".

Konflik batin merupakan masalah internal bagi seorang manusia. Misalnya, ada sesuatu hal yang terjadi akibat adanya pertentangan antara dua keinginan, keyakinan, pilihan yang berbeda, harapanharapan, atau masalah-masalah lainnya. Konflik batin dimunculkan dalam karya fiksi untuk menentukan kualitas, intensitas, dan kemenarikan suatu karya. Bahkan bisa dikatakan bahwa menulis cerita sebenarnya tidak lain adalah untuk membangun dan mengembangkan konflik. Untuk itulah pada penelitian ini akan diungkap konflik batin apa saja pada tokoh utama dalam novel Assalamualaikum Beijing.

\section{METODE PENELITIAN}

Jenis penelitian ini adalah jenis penelitian kualitatif dengan menggunakan metode deskriptif. Sugiyono (2010:8), menyebutkan bahwa metode penelitian kualitatif sering juga disebut sebagai metode penelitian naturalistik, karena penelitiannya dilakukan pada kondisi yang alamiah (natural setting); disebut juga sebagai metode etnographi, karena pada awalnya metode ini lebih banyak digunakan untuk penelitian bidang antropologi budaya; disebut juga sebagai metode kualitatif, karena data yang terkumpul dan analisisnya lebih bersifat kualitatif.

Data yang diambil adalah konflik batin yang dialami tokoh utama dalam novel Assalamualaikum Beijing karya Asma Nadia. Teknik pengumpulan data yang digunakan adalah teknik baca dan tulis. Data diperoleh secara langsung dengan membaca novel Assalamualaikum Beijing karya Asma Nadia. Setelah data terkumpul, kemudian dilakukan teknik penganalisisan data serta mendeskripsikan data tersebut. Penelitian ini bertujuan untuk menemukan dan mendeskripsikan konflik batin yang dialami oleh tokoh utama dalam novel Assalamualaikum Beijing karya Asma Nadia.

\section{HASIL DAN PEMBAHASAN}

Penelitian yang dilakukan terhadap konflik-konflik kejiwaan yang dialami para tokoh dalam cerita akan memberikan pengetahuan dan wawasan lebih dalam kepada penikmat sastra mengenai nilai sebuah karya sastra. Menurut Hartoko (dalam Redyanto, 2005: 93), pendekatan psikologi terhadap teks sastra dapat dilakukan secara deskriptif dengan melakukan penafsiran, dan teori psikoanalisis Freud. Menurut Sigmun Freud (dalam Diana, 2016:46), jiwa manusia memiliki tiga komponen, yaitu (1) id, yaitu sebuah dorongan alamiah jiwa manusia untuk melakukan suatu tindakan sesuai dengan kehendak dan keinginan dirinya sendiri. (2) super ego, yaitu sebuah wewenang untuk mengendalikan diri sendiri dan membatasi dengan keras keinginan-keinginan tanpa kendali dan tanpa pembatasan diri id. (3) ego, yaitu sebuah penyeimbangan antara tuntutan-tuntutan pengendalian diri dan pembatasan diri dan dorongan tanpa kendali. Dalam kedudukannya ego sebagai penyeimbang karena ego adalah kesadaran pikiran. 
Kesadaran inilah yang mengendalikan kata-kata, tindakan, pikiran seseorang dalam menghadapi suatu persoalan.

Konflik ialah sesuatu yang bersifat tidak menyenangkan yang dialami oleh tokoh dalam cerita. Peristiwa dan konflik biasanya berkaitan erat sehingga dapat menyebabkan satu dengan yang lain, bahkan konflik pun hakikatnya ialah peristiwa. Ada peristiwa yang dapat menyebabkan konflik. Begitupun sebaliknya, karena adanya konflik peristiwa lain pun akan bermunculan. Konflik demi konflik yang diiringi oleh peristiwa akan membuat konflik semakin meningkat, bahkan bisa mencapai titik puncaknya yang biasa disebut dengan klimaks. Menurut Stanton (dalam Diana, 2016: 48), konflik dapat dibedakan atas dua, yaitu (1) eksternal, yaitu konflik yang terjadi antara seorang tokoh dengan hal yang berada di luar dirinya. (2) internal, yaitu konfllik yang terjadi pada dalam diri, hati, atau jiwa seorang tokoh cerita. Kedua konflik tersebut saling berkaitan satu sama lain dan dapat juga terjadi secara bersamaan. Konflik internal dan konflik internal dalam karya sastra dapat berwujud konflik utama dan konflik tambahan. Menurut Nurgiantoro (2012:125), konflik utama pada umumnya terjadi pada tokoh utama cerita atau tokoh protagonist.

\section{Id}

Konflik batin yang dialami oleh tokoh utama dalam novel Assalamualikum Beijing karya Asma Nadia salah satunya, yaitu konflik yang berasal dari sifat dasar yang disebut sebagai konflik id. Tokoh Asma sering mengalami konflik dengan tokoh Dewa. Tokoh Asma dan Dewa ialah sepasang kekasih yang telah menjalin hubungan mereka semenjak di bangku perkuliahan dahulu. Mereka pun berencana untuk segera melanjutkan hubungan mereka kejenjang pernikahan, tetapi rencana mereka tidak akan pernah terwujud karena tokoh Dewa harus menikahi Anita yang telah dihamilinya. Peristiwa itu dapat dilihat alam kutipan novel berikut.

"Dan sebagai perempuan, dia tak akan bisa tidur tenang, jika bersikeras memaksa Dewa kembali, mengambil lelaki itu bukan hanya dari sisi Anita, yang telah menggoyahkan iman Dewa, tetapi juga dari janin yang kini dikandung perempuan itu." (Nadia, 2014: 65).

Konflik id selanjutnya yang dialami Asma adalah setelah membatalkan rencana pernikahannya dengan Dewa. Tokoh Asma pun mengalami sakit hati dan rasa kecewa yang sangat besar terhadap tokoh Dewa. Tokoh Asma pun pergi ke Beijing dengan tujuan untuk melupakan sakit hati dan rasa kecewanya terhadap tokoh Dewa. Keinginan tokoh Asma untuk pergi ke Beijing tersebut merupakan konflik id karena hal tersebut berasal dari dirinya sendiri. Selama berada di Beijing tokoh Asma bertemu dengan tokoh Zhongwen, mereka sering berbagi cerita dan pengalaman sehingga akhirnya Asma pun kembali membuka hati untuk Zhongwen.

Tokoh Asma juga merasakan konflik id pada saat ia dinyatakan menderita penyakit pengumpalan darah yang membuat ia susah untuk bergerak dan hampir mengalami kebutaan. Akibat penyakit yang dideritanya tersebut tokoh Asma pulang ke Indonesia kembali dan menjauhi Zhongwen. Peristiwa itu dapat dilihat dalam kutipan kutipan berikut.

"Dan Asma, yang saat ini kembali terbaring di rumah sakit beberapa minggu, mengira-ngira. Jika hanya rindu yang dimiliki seorang pria, akankah cukup untuk membuatnya setia? Rindu yang bertuang dalam pesan-pesan singkat melalui ponsel, beberapa postcard yang dikirim lelaki dengan hidung bangir itu dari berbagai daerah di China, dan teks saat mereka chatting." (Nadia, 2014: 207). 


\section{Ego}

Konflik ego memiliki kontak dengan dunia eksternal dari kenyataan. Ego ialah pelaksana dari kepribadian yang memerintah, mengendalikan, dan mengatur bagian id, super ego, dan dunia eksternal. Konflik ego mengendalikan kesadaran dan melaksanakan sensor. Konflik batin pada wilayah ego dialami oleh tokoh Asma karena ia merasa ragu untuk melanjutkan hubungannya dengan Zhongwen akibat penyakit yang diderita oleh tokoh Asma, dokter telah menyatakan bahwa ia akan sulit untuk mendapatkan seorang anak atau bahkan tidak bisa memiliki keturunan sama sekali. Hal tersebut membuat tokoh Asma menjauhi Zhongwen. Peristiwa tersebut dapat dilihat dalam kutipan novel berikut.

"Tentang Zhongwen, mungkin, perasaan ini lebih baik dilenyapkan sebelum semakin tumbuh dan akan terlalu menyakitkan ketika harapan tak seiring kenyataan." (Nadia, 2014: 207).

\section{Super Ego}

Super ego merupakan perwujudan konflik batin yang mengawasi ego secara dekat, menilai tindakan-tindakan dan niat-niatnya. Rasa bersalah terjadi ketika ego melakukan tindakan yang berlawanan dengan standar-standar moral super ego. Konflik batin pada wilayah super ego dalam novel Assalamualaikum Beijing karya Asma Nadia dapat dilihat pada tokoh Asma. Asma ialah kekasih Dewa semenjak ia masih berada di bangku perkuliahan. Pada saat Dewa mengkhianati cinta Asma ia tidak marah dan membentakbentak Anita. Asma lebih memilih untuk pergi ke Beijing agar dapat melupakan sakit hatinya dan rasa kecewanya terhadap Dewa.

Asma juga mengalami konflik batin wilayah super ego ketika ia mengalami sakit yang dideritanya. Sehingga Asma harus pergi meninggalkan Zhongwen, yaitu kekasih baru Asma yang merupakan seorang mualaf, tetapi Zhongwen terus mencari Asma dan pada akhirnya ia pun memutuskan untuk pergi ke Indonesia. Zhongwen bertemu dengan Asma di Indonesia ia merawat Asma dan menikah dengannya. Asma pun menyadari bahwa menjauhi Zhongwen bukan lah solusi dari masalahnya. Asma pun menikah dengan Zhongwen dan mereka dikaruniai dua orang anak.

\section{SIMPULAN}

Konflik batin merupakan masalah internal bagi seorang manusia. Misalnya, ada sesuatu hal yang terjadi akibat adanya pertentangan antara dua keinginan, keyakinan, pilihan yang berbeda, harapanharapan, atau masalah-masalah lainnya. Konflik batin dimunculkan dalam karya fiksi untuk menentukan kualitas, intensitas,dan kemenarikan suatu karya. Bahkan bisa dikatakan bahwa menulis cerita sebenarnya tidak lain adalah untuk membangun dan mengembangkan konflik. Konflik itu bisa dicari, ditemukan, diimajinasikan, dan dikembangan berdasarkan konflik yang dapat ditemui di dunia nyata. Jiwa manusia memiliki tiga kompone, yaitu (1) id, yaitu sebuah dorongan alamiah jiwa manusia untuk melakukan suatu tindakan sesuai dengan kehendak dan keinginan dirinya sendiri. (2) super ego, yaitu sebuah wewenang untuk mengendalikan diri sendiri dan membatasi dengan keras keinginan- keinginan tanpa kendali dan tanpa pembatasan diri id. (3) ego, yaitu sebuah penyeimbangan antara tuntutan- tuntutan pengendalian diri dan pembatasan diri, dan dorongan tanpa kendali. Dalam kedudukannya ego sebagai penyeimbang karena ego adalah kesadaran pikiran. Kesadaran inilah yang mengendalikan kata- kata, tindakan, pikiran seseorang dalam menghadapi suatu persoalan. Tokoh utama yang ada dalam novel yang berjudul Assalamualikum Beijing karya Asma Nadia mengalami konflik batin, yaitu Asma, Dewa, Anita, dan Zhongwen 


\section{DAFTAR PUSTAKA}

Ahmadi, A. (2007). Psikologi sosial. Jakarta : Rineka Cipa.

Arifuddin. (2014). An Analysis of social conflict in Rick Riordan's novel The Red Pyramid. Thesis. Makassar: Universitas Islam Negeri Makassar. http://repositori.uin-alauddin.ac.id/8593/1/AFIFUDDIN\%20\%28Thesis\%29.pdf

Diana, A. (2016). Analisis konflik batin tokoh utama dalam novel Wanita di Lautan Sunyi karya Nurul Asmayani. Jurnal Pesona, 2(1), 43-52. http://ejournal.stkipmpringsewu-lpg.ac.id/index.php/pesona

Nadia, A. (2014). Assalamualaikum Beijing. Depok: AsmaNadia Publishing House.

Nurgiyantoro, B. (2013). Teori pengkajian fiksi. Yogyakarta: Gajah Mada University.

Redyanto, N. (2005). Pengkajian sastra. Semarang: Fakultas Sastra Universitas Diponegoro.

Ristiana, K. R., \& Adeani, I. S. (2017). Konflik batin tokoh utama dalam novel Surga Yang Tak Dirindukan 2 karya Asma Nadia (Kajian psikologi sastra). Literasi: Jurnal Bahasa dan Sastra Indonesia serta Pembelajarannya, 1(2), 49-56.

Sugiyono. (2009). Metode penelitian pendidikan kuantitatif, kualitatif, dan $R \& D$. Bandung: Alfabeta. 